\title{
Genetically Modified Plants and Environmental Safety: A Critical Analysis ${ }^{1}$
}

\author{
PITELLI, R.A. ${ }^{2}$
}

\section{Initial considerations}

Biosecurity consists in a set of activities, studies, and procedures to prevent or control the risks posed by the use of chemical, physical, and biological agents to biodiversity and health.

The Brazilian regulatory process is internationally recognized as one of the strictest and most complete in the world. The $1^{\text {st }}$ Biosafety Law was enacted in January 1995 (Law no. 8.974/ 95) and only set the guidelines for the control of activities related to the exposure, handling, and use of organisms and products derived by recombinant DNA technology. A decade later, this law was replaced by a new Biosafety Law No. 11.105/05, which currently regulates the use of biotechnology in the country. This law establishes safety standards and mechanisms for monitoring activities involving genetically modified organisms - GMOs and their derivatives, creates the National Biosafety Council - CNBS, restructures the National Technical Commission on Biosafety - CTNBio and regulates the National Biosafety Policy - PNB.

Biosafety has several issues to be addressed in a suitable analysis of the risk/benefit, involving concerns about human and animal health, biodiversity, quality of abiotic resources, and the social and economic aspects.

Considering non-genetically modified plants, the most obvious scenario of concerns about biosafety refers to the numerous introductions of exotic plants in certain regions, causing damage to humans, animals and the environment (Ziller, 2001). These plants are usually factors of the dramatic increase in the use of pesticides, displacing native flora and affecting the entire associated food chain. Currently, many exotic invasive organisms are important factors in environmental degradation and health risks and there is no proportional concern with entities related to the regulation and protection of the environment and health.

Another important aspect of genetically modified plants that does not involve the recombinant DNA technique is the varieties obtained by ionizing radiation-induced mutation. In the early $21^{\text {st }}$ century $(2000) 2,252$ cultivated varieties obtained by radiation-induced mutations were registered, of which 1,585 were direct mutants and 667 were derived from crosses with mutant plants. This practice began in 1934 with the production of tobacco plants resistant to plant pathogens.

Ionizing radiation basically produces structural chromosomal changes and breaks in the DNA strands and is capable of producing morphological and physiological characteristics (intermediary metabolism) that are unique in the species. In reality, it is also about plants that are genetically modified without the direct manipulation of man over a particular gene sequence.

Plants obtained by radiation are grown and subjected to strong inspection by geneticists to eliminate deformed plants, plants with undesirable characteristics and plants that present no changes from the original variety. Only plants that have some distinctive and desirable trait for plant breeding are selected. Typically, only pleiotropic effects that are visually perceptible in the field study and greenhouse are eliminated in this first phase. For the registration of varieties, the nutritional composition of the plant is evaluated. There is no concern with other issues, such as plant ferality and environmental and social effects (Zanettini, 2001).

1 Recebido para publicação em 20.1.2014 e aprovado em 20.2.2014.

2 FCAV/UNESP, Jaboticabal, SP, Ecosafe Agricultura e Meio Ambiente SS Ltda., <rapitelli@ecosafe.agr.br>. 
The genetic modification in grown plants obtained by radiation and latent pleiotropic effects have not been considered very extensively by the regulatory agencies, but the risk can be much greater than that of the plants obtained by the recombinant DNA technique, wherein the modification is directed and pleiotropic changes are identified with the utmost rigor. Likewise, for the transgenic plants obtained there is also field selection.

\section{The evolution of genetically modified plants}

The genetic modification of plants of economic interest is quite old and began with the domestication process of cultivated plants. Natural populations suffered artificial selections, seeking the elimination of some factors of aggressiveness that created difficulties for human management. They can be cited as features removed or minimized: non-uniformity in the processes of germination, flowering and ripening, spontaneous dispersal of the diaspores, phenotypic plasticity, and other factors. The current crops are genetically very different from the original populations and very dependent on anthropogenic care for their survival.

These processes related to domestication were initially produced "selflessly" by indigenous peoples, early farmers, agricultural producers and, more recently, by researchers and farmers. Over time, the philosophy of adding value reached agriculture, and the production of commercial certified and hybrid seeds was a very important step in this process. At the time of release of the first corn hybrids, in which the seeds could not be reused, there was partial rejection and mobilization by farmers and society in the U.S., yet when they reaped the economic benefits related to productivity and product quality, they started to gradually accept the new technology.

In 1973, a scientific revolution began that would eventually greatly influence plant breeding. In that year, the first organism that was genetically modified by man was produced, a recombinant bacterium - Escherichia coli, with a gene of Salmonella. In 1981, the first genetically modified plant was obtained, and the first commercial crop approved for commercial planting in Brazil was the genetically modified glyphosate-tolerant soybean.

This text will only cover the agronomic and environmental technical-scientific aspects involved in the various forms of plants genetically modified for herbicide tolerance, resistance to adverse biotic factors, and abiotic stress tolerance.

\section{Plants genetically modified by the recombinant DNA technique}

Since the 1990s, genetic engineering techniques has been intensively developed and improved and have produced several differential events for the improvement of cultivated plants, such as tolerance to xenobiotic substances; resistance to biotic factors such as pests and diseases, tolerance to adverse abiotic factors, such as water restriction and temperature extremes; change of product quality, such as the protein content of food crops and fiber quality for the industry; and production of substances with pharmaceutical properties, perfume, and others. The modalities of genetically modified plants are many, and all provide various expectations of risks and benefits. This analysis will highlight and discuss the environmental risks inherent to some of the main types of genetically modified plants, especially those of great agricultural interest.

The assessment of genetically modified plants is the responsibility of the National Biosafety Technical Commission (CTNBio). Regardless of the purpose of the genetic modification, different information should be analyzed so that we can assess the risks of the new genotype.

To review the plant under analysis, CTNBio uses a wide range of information such as: (i) species, cultivation history and use of some parent for human and animal consumption; (ii) pleiotropic effects might result from the expression of the transgene, such as reduced fertility of the plant, increased susceptibility to pests, diseases and abiotic factors; (iii) reduction in the 
expression of the characteristics acquired in domestication; (iv) reproductive biology indicating whether autogamous or allogamous, which dispersal mechanism and pollen viability, potential pollinators; ( $\boldsymbol{v}$ ) parent presence in Brazilian biomes and in agroecosystems, with possibilities of cross-pollination; (vi) conditions of survival and viability of plant in natural environments and diaspores dispersal type; (vii) possibility that the inserted trait will be passed on to other species with adverse consequences such as the potential to affect the distribution and abundance of other species that received the inserted gene; (viii) whether the new characteristics introduced can modify the ability of the plant to add or remove substances from the soil; (ix) possibility that the introduced gene may cause an increase of plant toxicity for humans and animals; $(x)$ ecological side effects affecting endangered native species, providing the resistance of non-target populations to xenobiotic used in agriculture; $(x \boldsymbol{i})$ whether the construction confers resistance to another chemical agent other than selective agents such as antibiotics used in construction; and others. For these evaluations, CTNBio requires performing many studies and tests, including tests in silico (bioinformatics), testing in animal models (rats, mice, birds etc.), allergenicity testing and environmental testing.

With these data, CTNBio assesses the safety of the new variety and pronounces a technical decision in each case, on its biosafety and its derivatives in the context of the research and commercial use of GMOs and their derivatives, including the classification of the degree of risk and biosafety level required, as well as the safety measures required and usage restrictions. The post-commercial release monitoring is an item that can be required by CTNBio.

For each type of genetically modified plant there are peculiarities in the continuation of the registration process. After completing the requirements of the regulatory peculiarities for the approval of each modality, the process is again common to all genetically modified plants, which involves analysis and approval by the Council of Ministers. It is only after these steps are completed that the variety of the genetically modified plant can be submitted to the Ministry of Agriculture, Livestock and Food Supply - MAPA for cultivar registration and the release of production, transportation and marketing of the seed for commercial field planting.

\section{Plants genetically modified for herbicide tolerance}

Genetic modification of crops for herbicide tolerance is one of the most developed forms due to a large number of variables, such as: increased diversity and density of weed communities in agroecosystems; development of populations resistant to procedures used in conventional crops; difficulty in producing new active ingredients, due to technical aspects and rigor in registration laws; and the high added value of this kind of variety for seed producers.

The strategy of this type of genetically modified plant is the development of tolerance of the cultivated to an active ingredient to which it is susceptible or to a non-selective herbicide, allowing its use in the crop in question. In this type of genetically modified culture, the following analyses are performed: (i) the new genotype, under the responsibility of CTNBio; (ii) the herbicide; and (iii) the unprecedented use of a particular herbicide in a the culture, both under responsibility of the Ministries of Environment (IBAMA), Health (ANVISA) and Agriculture (MAPA).

The major environmental risk factor of any genetically modified plant is well conditioned to the gene flow to wild species, transferring the differential characteristic obtained by genetic engineering. In the case of plants genetically engineered for tolerance to herbicides, the result is relevant only in the areas where the herbicide is used, so that the lead can be expressed. Thus, the risk is quite relevant when the recipient wild species of the exotic invasive gene are agroecosystems, as occurred with the transfer of canola glyphosate resistance to brassica infesting crops in Canada (Warwick et al., 2003). The control of this weed is no longer efficient and it was necessary that old products were reinserted in management programs in the genetically modified crops. In the wild plants that live in natural areas, where there is no selective pressure of the herbicide, the population dynamics is not affected by the new feature and the plant expression in plant community is unchanged.

Planta Daninha, Viçosa-MG, v. 32, n. 1, p. 235-241,2014 
The development of populations of herbicide-resistant weeds is likely to occur and quite common in nature, but it is an event that is related to the herbicide and not the genetically modified plant. There has been a misinterpretation of the biological process of the development of weed resistance to glyphosate in cultures genetically modified for tolerance to this herbicide, as with the species of the genus Conyza, Digitaria insularis, Lolium multiflorum and others.

The development of resistance is a process of adaptive evolution of the weed to the selection pressure exerted by the herbicide, which, by geographic reach, frequency, and intensity of use, was enough pressure for the selection of biotypes that are naturally tolerant to the mode of action of the product (Pitelli, 2013). There was no direct relationship between the development of resistance and the fact that the culture is genetically modified for tolerance to the herbicide.

This fact is common and occurred in Brazil and worldwide in cultures conducted in large areas, before the existence of any plant genetically modified for herbicide tolerance. The example closest to Brazil is the populations of Bidens pilosa and Euphorbia heterophylla resistant to ALS inhibitors and Brachiaria plantaginea resistant to ACCase inhibitors in the late 1980s and early 1990s, in the states of Paraná and Rio Grande do Sul. This type of risk assessment should be carried out under the Ministry of Agriculture, Livestock and Supply, for it is the result of improper cultural practices. Undoubtedly, the development of resistant populations with the selection of tolerant biotypes is adequately addressed in Pitelli (2013). This author comments that, biologically, it is a process of adaptive evolution of populations facing a selection factor that becomes periodic. He points out that the breaking of the periodicity with rotations of crops, control practices and even products with different modes of action, it is feasible to prevent or delay the process of selecting tolerant biotypes. The adoption of good agricultural practices is the right attitude for preventing the development of resistance in various types of agricultural pests.

Weed resistance to herbicides can be attributed only to genetically modified plants when it is the result of direct gene flow. The risk assessment of this type of resistance is very important and is under the responsibility of CTNBio, by analyzing the possibility of gene flow via pollination to other parental weed species.

The possibility of a cultivated plant that acquires tolerance to a particular herbicide eventually becoming an invasive plant is negligible, since the domestication took so many of its characteristics of weediness and aggressiveness, that the mere introduction of a characteristic of tolerance to an herbicide is insufficient to alter their behavioral status in the agroecosystems (Pitelli \& Pavani, 2004).

\section{Plants genetically modified for resistance to pests and diseases}

Plants genetically modified for tolerance to biotic factors must have morphological, anatomical or physiological characteristics changed, so that they (i) obstruct the attack of the pest or pathogen infection, (ii) produce repellents to predators or inhibitors of pathogens germination and infection, or (iii) produce enough toxins to kill plant enemies. In this class of genetic modification, the biotype has had greater attention from CTNBio, especially regarding the effects of changes in the plant over its human and environmental toxicity. Regarding the commercial release of these genotypes, the environmental risks will be addressed below.

The effects on the fauna that inhabits agroecosystems are quite relevant, although the toxins expressed in cultivars sold today are quite specific. A risk/benefit analysis comparing crops resistant to insects and conventional crops by using insecticidal plants may show more dramatic effects of past practices, i.e. intensive use of chemicals against insects. Environmental monitoring studies have been conducted in areas with insect-resistant cultivars, showing that rates of diversity in arthropods have been high (Men et al., 2003) and there have also been benefits in the occupational health of rural workers (Pray et al., 2001).

Planta Daninha, Viçosa-MG, v. 32, n. 1, p. 235-241, 2014 
Gene flow to wild plants is a concern that depends on the habitat of the receiving species. In the case of ecosystem invasive plants, this additional characteristic is not of great relevance, since weeds are controlled within regular cultural practices.

In the case of plants that inhabit natural (non-agricultural) environments, changing characteristics that confer increased resistance to predators or parasites may be a temporary competitive advantage, depending on the importance of the target pest/disease to the wild plant. With this additional feature, the plant tends to increase its importance in the local plant community, but the processes involved in adaptive co-evolution of the relationship between the predator and host, after some time cause the biotic balance to again be restored (Pitelli \& Pavani, 2004).

A very important risk related to the competence of MAPA is the concern for the development of resistance in target pests to the characteristics expressed by the genetically modified plant. This is a real concern, since there are precedents (Stoter et al., 2010), and it is directly related to the lack of knowledge of good agricultural practices and application technology of agrochemicals.

The diversity of prey or hosts is critical to maintaining the characteristics and genetic diversity of the predator or parasite population. In order to avoid the restriction of hosts and selective pressure of the characteristic expressed by the genetically modified plant, it is critical to perform good agricultural practices such as crop rotation, maintenance of refuge areas to prevent resistance, the use of pesticides used with different modes of action, among others (Frizzas \& Oliveira, 2006; Wu et al., 2005).

In both cases - herbicide-tolerant plants or plants resistant to biotic factors - the development of resistance in target control populations is a biological behavior expected of adaptive evolution and may constitute serious prejudice to the technology holders, since farmers have options to change technologies in order to solve their problems.

\section{Plants genetically modified for tolerance to abiotic stress}

Plants genetically modified for tolerance to abiotic stress may show changes in their ecophysiological behavior related to: (i) morphological changes, such as the structure of the root system, plant architecture, number, structure and distribution of stomata; (ii) intermediary metabolism, producing substances with "detoxing" properties; and (iii) changes in resource partitioning within the plant, and others. Plants genetically modified for different behavioral characteristics have been produced, such as tolerance to soil salinity, concentrations of toxic elements (Al, Mn and heavy metals), restriction of moisture, low availability of oxygen in the root system, adverse temperatures and others.

The risk inherent to genetically modified organisms is analyzed by CTNBio, and again, special attention should be paid to the possibility of gene flow to wild plants. Although the cultivated plant might have acquired characteristics that minimize abiotic pressure, loss of a number of aggressive factors and roughness during domestication causes the risk of it becoming invasive in any environment to be considered as extremely low or negligible.

As for gene flow to wild plants, invasive or not, the projected scenarios show the real existence of risks (Pitelli; Pavani, 2004). If there is a gene flow from transgenic crops to wild species, transferring characteristics related to abiotic stress tolerance, the risk will relate to the possibility of changing their occurrence and frequency at different times and places of colonization. A fairly didactic example would occur when there was gene flow from a genetically modified plant transferring tolerance to water stress to a wild plant. In regions with well-defined hydric seasons, this wild plant can grow and reproduce effectively in adverse water conditions, which was not typical of the original species and all other populations composing that plant community. Over time, the relative importance of this species in the community may be 
increased at the expense of the others, reducing the diversity index of the plant community. Unlike resistance to biotic pressures, there is the process of coevolution involved in this new feature of the genotype. This same reasoning can be applied to the geographical distribution of the favored species, as well as for tolerance to stresses promoted by other abiotic factors such as the toxicity of aluminum and other elements, and other improper temperatures.

With regard to invasive wild plants in agroecosystems, these changes will allow the importance of weeds to increase in crops and areas where it is not so essential. However, it is important to consider that this risk is subjected to control in terms of management practices adopted by the farmer.

Anyway, in order for these risks to be real, it is essential that gene flow and the expression of transgenesis in wild plants do occur. This flow is negligible for crops genetically modified by the recombinant DNA technique that are available in the Brazilian market, such as soybeans and corn. For cotton, the gene flow prevention measures adopted have been sufficient to minimize the risk.

\section{Final considerations}

The genetic changes in populations of cultivated plants started since the dawn of agriculture - the process known as domestication, in which unwanted behavioral characteristics were eliminated or minimized for the plant management by man. Obtaining varieties altered by ionizing radiation was accepted, and they were marketed without major reviews of the health and environmental risks. The production of commercial hybrids represented other developments in the production of crops and provided controversy at the time, due to the commercial character of the process. The last major development in the production of crops was provided by genetic engineering, when man began to manipulate the desired changes objectively and concretely inserting features interspecifically.

Due to the new and innovative character of this type of variety production technology, there was great concern in the scientific community and society, especially regarding the lack of more specific information about the safety of these products (especially food) and the environmental effects that were likely to occur. At that time, discussions were held, discussion and regulatory committees were created and, gradually, society arrived at the idea that many risks were negligible and others were fairly important. The elaboration of specific laws and the creation of committees for biosafety review (CTNBio, Brazil) were an important step in the analysis and subsequent release of these genetically modified organisms.

With the planting time of genetically modified plants, some low risk predictions started being confirmed, while some undesirable effects, already predicted, were not prevented by a lack of implementation of good agricultural practices. This comment is directed to the development of weed populations resistant to herbicides and insect resistance to toxins expressed in insect-resistant plants. These two phenomena were widely known before the introduction of genetically modified plants.

The modern trend of the production of plants with staked, i.e. combined, events increases the task and accuracy of CTNBio in the analysis of food and environmental safety of new genotypes from regulatory agencies ANVISA, IBAMA and MAPA, in the assessments of xenobiotic substances, if used, and in the registry of cultivars at MAPA.

\section{Literature Cited}

FRIZZAS, M. R.; OLIVEIRA, C. M. Plantas transgênicas resistentes a insetos e organismos-não-alvos: predadores, parasitóides e polinizadores. Universitas: Ciências da Saúde, v. 4, n. 1⁄2, p. 63-82, 2006.

MEN, X.; GE, F.; LUI, X.; YARDIM, E. N. Diversity of arthropod communities in transgenic Bt cotton and nontransgenic cotton agroecossystems. Environmental Entomology, v. 32, n. 2, p. 270-275, 2003.

Planta Daninha, Viçosa-MG, v. 32, n. 1, p. 235-241, 2014 
PITELLI, R. A.; PAVANI, M. C. M. D. Feralidade e trangienese. In: BOREM, A. (Org.). Biotecnologia e meio ambiente. Viçosa: UFV, 2004. p. 263-278.

PITELLI, R.A. Biologia e evolução de plantas daninhas resistentes aos herbicidas. Serie Tecnica INIA Paraguay, v. 204, p. 27-33, 2013.

PRAY, J.; DANMENG, M. A.; HUANG, J.; QIAO, F. Impact of Bt cotton in China. World Development, v. 29, n. 5, p. 813-825, 2001.

STOTER, N .P.; BABCOCK, J. M.; SCHLENZ, M.; MEADE, T.; THOPSON, G. D.; BING, J. M.; HUCKABA, R. M. Discovery and characterization of field resistance to Bt maize: Spodopetra frugiperda (Lepidoptera Noctuidae) in Puerto Rico. Journal of Economic Entomology, v. 103, n. 4, p. 1031-1030, 2010.

WARWICK, S. J.; SIMARD, M. J.; LÉGERE, A.; BECKIE, H. J., BRAUN, L. ZHU, B. MASON, P. SÉGUIN-SWARTZ, G.; STEWART, C. N. Hybridization between transgenic Brassica napus L. and its wild relatives: Brassica rapa L, Raphanus raphanistrum L, Sinapis arvensis L. and Erucastrum gallicum (Willd.) O.E. Schulz. Theor. Appl. Genet., n. 107, p. 528-539, 2003.

WU, K.; MU, W.; LIANG, G.; GUO, Y. Regional reversion of insecticide resistance in Helicoverpa armigera (Lepidoptera: Noctuidae) is associated with the use of Bt cotton in Northern China. Pest Management Science, v. 61, p. 491-498, 2005.

ZILLER, S. R. Plantas exóticas invasoras: a ameaça da invasão biológica. Ciência Hoje, v. 30, n. 178, p. 77-79, 2001.

ZANETTINI, M. H. B. Análise de risco: alimentos vegetais derivados do melhoramento convencional x plantas geneticamente modificadas, In: JORNADAS NACIONALES DE ENSEÑANZA DE LA BIOLOGÍA, 5., 2001, Missiones, Argentina. Anales... Missiones, Argentina, 2001. p. 129-131. 